DOI: https://doi.org/10.47405/mjssh.v6i8.949

\begin{tabular}{|c|c|}
\hline 4 & Malaysian Journal of Social Sciences and Humanities (MJSSH) \\
\hline $\begin{array}{l}\text { Malaysian Juoural of } \\
\text { Social ccciecces and }\end{array}$ & Volume 6, Issue 8, August 2021 \\
\hline (MJ-sSH) & e-ISSN : 2504-8562 \\
\hline & $\begin{array}{l}\text { Journal home page: } \\
\text { www.msocialsciences.com }\end{array}$ \\
\hline
\end{tabular}

\title{
Kesediaan dan Efikasi Guru Matematik Sekolah Rendah dalam Pengintegrasian Teknologi Semasa Pandemik COVID-19
}

\author{
Nurul Farahin Ab Aziz¹, Siti Mistima Maat ${ }^{1}$ \\ ${ }^{1}$ Fakulti Pendidikan, Universiti Kebangsaan Malaysia (UKM)
}

Correspondence: Nurul Farahin Ab Aziz (nurulfarahin6208@gmail.com)

\begin{abstract}
Abstrak
Banyak negara mengambil keputusan untuk melaksanakan pengajaran dan pembelajaran (PdP) atas talian dengan memanfaatkan Teknologi Maklumat dan Komunikasi (TMK). Walau bagaimanapun, didapati ramai guru matematik masih lemah dalam aspek penguasaan ilmu, pengkaedahan PdP, penggunaan dan kepercayaan serta sikap terhadap TMK dalam pendidikan. Oleh yang demikian, perlaksanaan kajian ini adalah bertujuan untuk mengenal pasti kesediaan dan efikasi guru matematik dalam pengintegrasian teknologi sewaktu pandemik COVID-19. Faktor jantina, tempoh perkhidmatan dan Pengetahuan Teknologi Pedagogi Isi Kandungan (PTPIK) guru matematik turut diambil kira. Kajian ini menggunakan reka bentuk tinjauan keratan rentas dengan memanfaatkan pensampelan mudah ke atas 62 guru matematik sekolah rendah Kuala Selangor. Analisis statistik deskriptif dan inferensi digunakan bagi tujuan penganalisisan data kajian. Analisis deskriptif menunjukkan pengetahuan guru matematik berada pada tahap yang tinggi. Analisis statistik inferensi menunjukkan perbezaan tidak signifikan bagi kesediaan dan efikasi guru matematik dalam pengintegrasian teknologi berdasarkan jantina dan tempoh perkhidmatan. Selain itu, efikasi guru matematik mempunyai hubungan linear yang signifikan ke atas kesediaan guru matematik dalam pengintegrasian teknologi. Implikasi terhadap peranan guru matematik dan pihak kepimpinan dibincangkan dengan berfokuskan kepentingan latihan dalam perkhidmatan bagi memastikan pengetahuan, kesediaan dan efikasi guru matematik sentiasa berada di tahap yang memuaskan. Banyak usaha yang perlu dilakukan bagi memastikan keberhasilan pengajaran matematik sewaktu pandemik COVID-19.
\end{abstract}

Kata kunci: kesediaan, efikasi, guru matematik, integrasi teknologi, pengetahuan teknologi

\section{Primary School Mathematics Teachers' Readiness and Efficacy in Technology Integration During the Pandemic COVID-19}

\begin{abstract}
Many countries have decided to proceed the teaching and learning (TnL) process by using Information and Communication Technology (ICT). However, mathematics teachers are still weak in the aspects of knowledge mastery, TnL methodology, uses and beliefs as well as attitudes towards ICT in education. Therefore, the purposes of this study is to identify the readiness and efficacy of mathematics teachers in technology integration during the COVID-19 pandemic. Factors of gender, years of service and Technological Pedagogical and Content Knowledge (TPACK) of mathematics teachers are also taken into account. This study used cross-sectional survey on 62 primary school mathematics teachers in Kuala Selangor by using convenience sampling. Descriptive and inferential analyses were used for data analyses purpose. Descriptive analysis showed that the knowledge of mathematics teachers is at a
\end{abstract}


high level. Inferential statistical analysis showed insignificant differences of readiness and efficacy of mathematics teachers in technology integration based on gender and years of service. In addition, the efficacy of the mathematics teachers has significant linear relationship with the readiness of mathematics teachers in technology integration. Implications for mathematics teachers and leadership were discussed with a focus on in-service training interest so that the knowledge, readiness and efficacy of mathematics teachers are always within satisfactory. Much effort is required in conducting a successful mathematics TnL during the pandemic COVID-19.

Keywords: readiness, efficacy, mathematics teachers, technology integration, technology knowledge

\section{Pengenalan}

Sektor pendidikan adalah sektor kedua yang terjejas teruk disebabkan pandemik COVID-19 (Hebebci et al., 2020). Ini terbukti apabila lebih daripada 100 buah negara terpaksa melaksanakan penutupan sekolah, yang secara tidak langsung telah menjejaskan separuh populasi pelajar (UNESCO, 2020). Malaysia juga tidak terkecuali apabila pembelajaran seramai 4.9 juta orang pelajar turut terjejas dek penutupan sekolah bermula pertengahan bulan Mac 2020 (Abdul Hamid \& Khalidi, 2020). Bagi mengatasi perkara ini, banyak negara mengambil keputusan untuk melaksanakan pengajaran dan pembelajaran (PdP) atas talian dengan memanfaatkan Teknologi Maklumat dan Komunikasi (TMK), antaranya negara Amerika Syarikat (Johns \& Mills, 2020), negara Indonesia (Bahasoan et al., 2020), negara Zambia (Mulenga \& Marbán, 2020) dan lain-lain. Manakala, di Malaysia, Kementerian Pelajaran Malaysia (KPM) telah melaksanakan Pengajaran dan Pembelajaran di Rumah (PdPR) pada penghujung tahun 2020 (Kementerian Pendidikan Malaysia, 2020). Malahan, pelaksanaan tersebut berlanjutan hingga tahun 2021 (Kementerian Pendidikan Malaysia, 2021).

Lantaran itu, ramai guru berada dalam kerisauan terhadap kesediaan mereka dan keberkesanan perlaksanaan ini kerana faktor-faktor halangan dalam menjalankan PdP atas talian sewaktu pandemik ini (Bahasoan et al., 2020; Mohalik \& Sahoo, 2020; Putra et al., 2020). Banyak kajian yang dijalankan saat pandemik ini adalah bagi mengenal pasti halangan-halangan yang dihadapi oleh para guru dan pelajar keseluruhannya seperti kajian oleh Ali (2020), Awofala et al. (2020), Kamsurya (2020), Putra et al. (2020) dan Sokal et al. (2020). Walau bagaimanapun, kajian-kajian tersebut lebih banyak berfokuskan kepada persepsi guru-pelajar terhadap pelaksanaan PdP atas talian berbanding mengkaji elemen-elemen kendiri yang perlu dibaik pulih bagi memastikan keberhasilan PdP atas talian sewaktu pandemik COVID-19. Walaupun sebelum pandemik ini berkunjung tiba menjengah penduduk dunia, didapati ramai guru matematik masih lemah dalam aspek penguasaan ilmu, pengkaedahan PdP, penggunaan dan kepercayaan serta sikap terhadap TMK dalam pendidikan (Dong et al., 2020; Fahrurozi et al., 2019; Fontanilla, 2015; Jung et al., 2019; Kariki et al., 2017; Simsek \& Yazar, 2019; Şen, 2020; Valtonen et al., 2020; Yang, 2018).

Perkara ini berikutan daripada pengalaman dan pengetahuan pengintegrasian dalam kalangan guru matematik yang tidak mencukupi walaupun kemudahan komputer dan capaian internet semakin meluas (Kariki et al., 2017; Sahin Izmirli \& Kirmaci, 2017). Namun, tidak dapat dinafikan bahawa pengintegrasian teknologi dalam pendidikan bukanlah satu norma penting bagi beberapa bidang pengajaran, atau mungkin tidak bersesuaian dengan disiplin ilmu tertentu (Simsek \& Yazar, 2019). Walau bagaimanapun, guru matematik perlu sedar bahawa pengintegrasian teknologi dalam pengajaran matematik perlu dilakukan dengan segera bagi memberikan jaminan terhadap keberhasilan PdPR. Oleh kerana itu, perkara ini berbalik kepada tahap efikasi kendiri guru matematik dalam mengintegrasikan teknologi. Tanpa mereka sedar efikasi kendiri turut mencerminkan kepercayaan dan sikap mereka terhadap kemampuan diri dalam melaksanakan PdP dengan menggunakan teknologi (Dong et al., 2020; Jung et al., 2019; Kapici \& Akcay, 2020).

Perkara ini turut menjadi lebih kritikal apabila tidak banyak penyelidikan dilaksanakan untuk mengenal pasti dan membezakan hubungan antara sikap terhadap teknologi, kesediaan guru dan 
kemampuan seorang guru untuk mengintegrasikan teknologi dengan berkesan (El-daou, 2016). Tambahan, banyak kajian berkaitan pengintegrasian teknologi ini dilaksanakan terhadap guru pelatih berbanding guru dalam perkhidmatan (Akturk \& Saka Ozturk, 2019; Fontanilla, 2015). Justeru, kajian ini dilaksanakan bagi mengenal pasti kesediaan dan efikasi guru matematik dalam pengintegrasian teknologi sewaktu pandemik COVID-19. Faktor jantina, tempoh perkhidmatan dan Pengetahuan Teknologi Pedagogi Isi Kandungan (PTPIK) guru matematik turut diambil kira kerana, menurut Holden dan Rada (2011), faktor-faktor peribadi ini amat berkait dengan sikap dan persepsi guru terhadap penggunaan teknologi.

\section{Objektif Kajian}

i. Menentukan tahap Pengetahuan Teknologi (PT), Pengetahuan Teknologi Isi Kandungan (PTIK), Pengetahuan Teknologi Pedagogi (PTP) dan Pengetahuan Teknologi Pedagogi Isi Kandungan (PTPIK) guru matematik berdasarkan min skor.

ii. Membandingkan kesediaan dan efikasi guru matematik dalam pengintegrasian teknologi berdasarkan jantina dan tempoh perkhidmatan.

iii. Mengenal pasti pengaruh Pengetahuan Teknologi (PT), Pengetahuan Teknologi Isi Kandungan (PTIK), Pengetahuan Teknologi Pedagogi (PTP) dan Pengetahuan Teknologi Pedagogi Isi Kandungan (PTPIK) dan efikasi guru matematik ke atas kesediaan guru matematik dalam pengintegrasian teknologi.

\section{Hipotesis Kajian}

Hipotesis nol : Tidak terdapat perbezaan kesediaan dan efikasi guru matematik dalam pengintegrasian teknologi berdasarkan jantina.

Hipotesis nol : Tidak terdapat perbezaan kesediaan guru matematik dalam pengintegrasian teknologi berdasarkan tempoh perkhidmatan.

Hipotesis nol : Tidak terdapat perbezaan efikasi guru matematik dalam pengintegrasian teknologi berdasarkan jantina.

Hipotesis nol : Tidak terdapat perbezaan efikasi guru matematik dalam pengintegrasian teknologi berdasarkan tempoh perkhidmatan.

Hipotesis nol : Tidak terdapat pengaruh antara Pengetahuan Teknologi (PT), Pengetahuan Teknologi Isi Kandungan (PTIK), Pengetahuan Teknologi Pedagogi (PTP) dan Pengetahuan Teknologi Pedagogi Isi Kandungan (PTPIK) dan efikasi guru matematik ke atas kesediaan guru matematik dalam pengintegrasian teknologi.

\section{Sorotan Literatur}

Pelbagai cabaran akan timbul apabila pengintegrasian teknologi ke dalam pendidikan dilakukan. Oleh yang demikian, guru matematik perlu ambil cakna akan halangan-halangan yang dihadapi dan bakal dihadapi oleh mereka. Bagi memudahkan kefahaman, halangan telah dikategorikan kepada dua iaitu halangan pertama dan halangan kedua oleh Ertmer (1999). Ringkasnya, halangan pertama adalah halangan yang berada di luar kawalan seorang guru matematik (Amick, 2019) iaitu halangan yang berkait dengan akses dan sumber (Brown, 2015) seperti peralatan, masa, latihan dan sokongan (Fontanilla, 2015; Knapp, 2017). Walau bagaimanapun, Hew dan Brush (2007) menyatakan halangan pertama adalah merangkumi faktor-faktor persekitaran seperti kesediaan persekitaran, pengetahuan dan kesediaan guru. Menariknya, pendapat tersebut sejajar dengan definisi halangan kedua oleh Ertmer yang antaranya merangkumi sikap, kepercayaan, pengetahuan dan kemahiran seorang guru matematik (Amick, 2019). Dalam erti kata lain, halangan kedua ini adalah berakar daripada 
kepercayaan yang mendasari guru matematik mengenai PdP. Selain itu, halangan-halangan PdP yang dihadapi saat pandemik ini lebih jelas kelihatan dan membuka mata pelbagai pihak bagi mencari solusinya. Antara halangannya adalah ketidakcukupan data jalur lebar dan kekangan capaian jalur lebar (Putra et al., 2020), tekanan atau sindrom burnout (Sokal et al., 2020), kekangan aspek perancangan dan penyediaan (Ali, 2020; Kamsurya, 2020), kekangan alat teknologi (Ali, 2020; Kamsurya, 2020), kesediaan dan keyakinan guru (Ali, 2020; Kamsurya, 2020), sikap (Awofala et al., 2020) dan lain-lain.

Walau bagaimanapun, hakikatnya, kemenjadian pendidikan berasaskan teknologi amat bergantung kepada kesediaan guru matematik (Petko et al., 2018). Saat COVID-19 ini, guru matematik diminta untuk bersedia dengan segera dalam pengintegrasian teknologi dalam pengajaran (Lapada et al., 2020). Antaranya bersedia dengan kemahiran-kemahiran menggunakan teknologi dalam talian yang pelbagai seperti portal pendidikan atas talian, Microsoft Team, Zoom, Google Meet dan lain-lain (Mallillin et al., 2020). Walau bagaimanapun, perkara ini seakan-akan tidak menjadi kenyataan apabila pengintegrasian teknologi yang mengejutkan ini tidak memberikan peluang kepada guru matematik untuk membuat persediaan dalam perancangan pembelajaran, penilaian dan pengurusan teknikal (Mohalik \& Sahoo, 2020). Ini dapat dilihat dalam kajian Lapada et al. (2020) yang mendapati hanya $58 \%$ daripada 2300 orang guru bersedia untuk menggunakan modul atau bahan pengajaran atas talian seperti Youtube, Ted Talk dan Khan Academy. Ini turut sejajar dengan dapatan kajian König et al. (2020) yang mendapati hampir $70 \%$ daripada 165 orang guru tidak menggunakan peralatan digital dalam menyediakan pembelajaran atas talian. Ini menunjukkan bahawa penggunaan teknologi atas talian tidak berada di tahap yang maksima. Walau bagaimanapun, kajian Mallillin et al. (2020) menyatakan tiada perbezaan signifikan terhadap kesediaan guru dalam menghadapi transisi pengajaran fizikal kepada atas talian kerana kebiasaan mereka menggunakan teknologi dalam pengajaran.

Oleh kerana itu, kajian-kajian lepas yang dilaksanakan mendapati kepercayaan efikasi kendiri adalah antara faktor yang memainkan peranan ke atas keputusan guru dalam mengintegrasikan teknologi (ELDaou, 2016; Farah, 2011; Wang et al., 2004). Kepercayaan dan sikap guru terhadap penggunaan teknologi adalah pertimbangan genting dalam menjayakan pengintegrasian teknologi (Fontanilla, 2015; Jung et al., 2019). Pendek kata, jika tahap efikasi teknologi seseorang guru itu tinggi, ia akan mendorong guru tersebut untuk mengambil risiko dalam mengembangkan dan mengintegrasikan penggunaan teknologi dalam konteks pendidikan sebaik mungkin (Durak, 2019). Namun, menariknya, kajian Abu Bakar et al. (2020) yang dilaksanakan bagi mengenal pasti tahap efikasi guru matematik dalam mengintegrasikan teknologi berdasarkan jantina dan tempoh pengalaman mengajar mendapati bahawa tiada perbezaan yang signifikan bagi kedua-kedua faktor tersebut. Dapatan kajian tersebut bertentangan dengan kajian Bahador et al. (2018) yang mendapati guru berpengalaman lebih daripada 11 tahun lebih cenderung dan berkebolehan dalam mengintegrasikan teknologi berbanding guru yang mempunyai pengalaman bawah 10 tahun. Malahan kajian Farah (2011) menemukan bahawa guru lelaki adalah lebih ramai yang mempunyai efikasi yang tinggi dalam mengintegrasikan teknologi berbanding guru perempuan.

Lantaran itu, pengetahuan seorang guru matematik dalam mengintegrasikan teknologi perlu dilihat semula kerana Dinc (2019) menyatakan pengetahuan dan kemahiran yang kukuh adalah berkesan bagi mengubah sikap, kepercayaan dan keyakinan keupayaan diri dalam mengintegrasikan teknologi. Oleh yang demikian, Mishra dan Koehler (2006) telah mencadangkan konstruk Pengetahuan Teknologi Pedagogi Isi Kandungan (PTPIK) yang menitikberatkan pengintegrasian teknologi dalam pengajaran seorang guru matematik kerana tindakan sedemikian dapat mengubah pembelajaran pasif kepada pembelajaran yang lebih aktif dan efektif. Kajian Valtonen et al. (2020) pula mendapati guru pelatih masih mempunyai tahap PTPIK yang rendah walaupun mempunyai sikap yang positif terhadap pengintegrasian teknologi. Ini berikutan, pengintegrasian teknologi masih lagi mencabar buat guru pelatih yang tidak bersedia dan tidak menguasai Pengetahuan Teknologi Pedagogi (PTP) yang memerlukan kemahiran mereka untuk mengendalikan PdP atas talian untuk tujuan yang betul iaitu penggunaan internet bagi menyokong pembelajaran, bukannya untuk tujuan hiburan (Valtonen et al., 2020). 
Malahan, kajian Sarwa et al. (2020) mendapati masih terdapat guru yang berada dalam keraguan (19.6\%) dan 6.4\% guru tidak bersedia untuk menerapkan PTPIK bagi memenuhi kompetensi guru pada abad ke-21. Tiba dan Condy (2021) pula menyimpulkan bengkel-bengkel yang diadakan oleh pihak fakulti adalah tidak mencukupi untuk mempersiapkan guru pelatih untuk mengajar menggunakan teknologi. Ini dikuatkan lagi dengan kenyataan oleh Chaaban dan Moloney (2016) serta İşler dan Yıldırım (2018) yang menyatakan bahawa bengkel TMK tidak menawarkan kemahirankemahiran yang mengadunkan teknologi, pedagogi dan isi kandungan kepada para guru. Menyedari hakikat di atas, banyak usaha yang perlu dilakukan bagi memastikan keberhasilan pengajaran matematik sewaktu pandemik COVID-19. Tidak dinafikan, kesediaan guru adalah didasarkan pada kepercayaan terhadap manfaat pendidikan berasaskan teknologi dan keyakinan terhadap keupayaan diri dalam menggunakan teknologi, mampu untuk melonjakkan lagi peratusan pengintegrasian teknologi dalam PdP (Petko et al., 2018) dalam kalangan guru matematik yang bukan hanya bergantung kepada modul dan bahan bercetak semata-mata.

\section{Metod Kajian}

\section{Rekabentuk Kajian}

Bagi mencapai objektif kajian ini, reka bentuk tinjauan keratan rentas dilaksanakan bagi meninjau kesediaan dan efikasi guru matematik dalam pengintegrasian teknologi. Reka bentuk tinjauan keratan rentas membenarkan peninjauan terhadap sikap, kepercayaan, pendapat atau amalan responden kajian dilakukan (Bhattacherjee, 2012). Ini bermakna, kajian ini dijalankan dengan menggunakan pendekatan kuantitatif bagi tujuan menjawab hipotesis melalui pengumpulan data berangka (Humes, 2017). Pendekatan ini digunakan kerana mampu memberikan penemuan yang sah (Mailizar et al., 2020) selain membolehkan penganalisisan tren, perbandingan kumpulan atau perkaitan antara pemboleh ubah dalam dilakukan (Creswell, 2014).

\section{Populasi dan Pensampelan}

Guru-guru matematik peringkat rendah di bawah pentadbiran dan pengurusan Pejabat Pendidikan Daerah (PPD) Kuala Selangor, Selangor telah dipilih sebagai populasi kajian ini. Hal ini demikian kerana, menurut Jan (2020), pelaksanaan pengajaran atas talian di Malaysia saat COVID-19 di peringkat rendah masih lagi belum mencapai keberkesanan yang sempurna dan pengajaran guru masih lagi dipengaruhi gaya pengajaran bersemuka. Selain itu, kaedah pensampelan mudah telah dimanfaatkan. Kaedah pensampelalan ini memudahkan pengkaji untuk mendapatkan sasaran responden (Etikan, 2016) secara atas talian melalui WhatsApp dan Telegram yang menjadi antara perisian utama komunikasi kini.

Dalam pada itu, sebanyak 62 maklum balas telah diperoleh setelah pengumpulan data sebenar dilakukan melalui Google Form yang telah diedarkan. Google Form dimanfaatkan kerana pautan URL dapat dihasilkan bagi tujuan pengedaran soal selidik atas talian serta maklum balas dapat direkodkan ke dalam bentuk lembaran yang membolehkan data untuk dieksport ke perisian statistik untuk tujuan penganalisisan (Vasantha Raju \& Harinarayana, 2016). Maklumat demografi jantina (Jadual 1) dan tempoh perkhidmatan (Jadual 2) adalah seperti di bawah.

Jadual 1: Taburan guru matematik peringkat rendah berdasarkan jantina

\begin{tabular}{lll}
\hline Jantina & Kekerapan & Peratusan (\%) \\
\hline Lelaki & 17 & 27.4 \\
Perempuan & 45 & 72.6 \\
Jumlah & 62 & 100.0 \\
\hline
\end{tabular}


DOI: https://doi.org/10.47405/mjssh.v6i8.949

Jadual 2: Taburan guru matematik peringkat rendah berdasarkan tempoh perkhidmatan

\begin{tabular}{lll}
\hline Tempoh Perkhidmatan & Kekerapan & Peratusan $(\%)$ \\
\hline Kurang dari 7 tahun & 2 & 3.2 \\
7 tahun hingga 10 tahun & 5 & 8.1 \\
11 tahun hingga 18 tahun & 18 & 29.0 \\
Lebih dari 18 tahun & 37 & 59.7 \\
\hline Jumlah & 62 & 100.0 \\
\hline
\end{tabular}

\section{Instrumen Kajian}

Kajian ini telah mengadaptasi sembilan konstruk daripada empat soal selidik yang berbeza. Antara soal selidik yang telah diadaptasi dalam kajian ini adalah konstruk literasi teknikal daripada $K$ to 12 Blended Teaching Readiness oleh Graham et. al (2019), reka bentuk kursus dan komunikasi kursus daripada Faculty Readiness Competencies oleh Martin et. al (2019), strategi dan keupayaan menggunakan teknologi komputer dan halangan luaran dalam menggunakan teknologi komputer daripada Computer Technology Integration (CTI) oleh Wang et al. (2004) serta Pengetahuan Teknologi (PT), Pengetahuan Teknologi Isi Kandungan (PTIK), Pengetahuan Teknologi Pedagogi (PTP) dan Pengetahuan Teknologi Pedagogi Isi Kandungan (PTPIK) daripada Perceived Expertise with Mathematics Content, Pedagogy and Digital Technologies Knowledge(TPACK) oleh Alshehri (2012).

Konstruk-konstruk yang telah diadaptasi kemudiannya, telah diterjemahkan kepada bahasa Melayu dengan menggunakan back translations yang bertujuan bagi menterjemahkan kembali versi bahasa sasaran kepada bahasa sumber asal untuk pengesahan penterjemahan instrumen ini (Maneesriwongul \& Dixon, 2004) oleh seorang pakar bahasa. Setelah itu, instrumen kajian ini diberikan kepada dua orang pakar kesahan kandungan yang bertujuan bagi mengenal pasti kemampuan instrumen kajian bagi mengukur konstruk kajian (Salwana \& Norasmah, 2020). Tambahan, 43 maklum balas yang berjaya direkodkan bagi kajian rintis yang dilakukan. Kebolehpercayaan item dikira dengan menggunakan perisian Statistical Package for Social Science (SPSS) versi 25.0. Menurut Hair et al. (2014), nilai Cronbach Alpha sebaik-baiknya melebihi nilai 0.70. Oleh yang demikian, nilai Cronbach Alpha bagi kajian rintis adalah 0.988, manakala nilai Cronbach Alpha bagi kajian sebenar adalah 0.986 .

\section{Tatacara Penganalisisan Data}

Statistical Package for Social Science (SPSS) versi 25.0 dimanfaatkan bagi penganalisisan data yang direkodkan. Satu analisis deskriptif telah dilakukan bagi membandingkan skor min tahap PT, PTIK, PTP dan PTPIK. Julat (Jadual 3) yang ditentukan berdasarkan pengiraan rumus oleh TschannenMoran dan Gareis (2004).

Jadual 3: Interpretasi skor min

\begin{tabular}{ll}
\hline Julat Skor Min & Interpretasi Skor Min \\
\hline 1.00 hingga 1.75 & Sangat rendah \\
1.76 hingga 2.50 & Rendah \\
2.51 hingga 3.25 & Sederhana \\
3.26 hingga 4.00 & Tinggi \\
\hline
\end{tabular}

Penganalisisan data diteruskan dengan ujian $\mathrm{t}$ tidak bersandar, ujian ANOVA satu hala dan regresi linear berganda setelah data mencapai taburan normal dengan nilai kepencongan dan kurtosis berada dalam lingkungan \pm 1.96 , dengan tahap ralat adalah 0.05 (Hair et al., 2014). Analisis ujian t tidak bersandar dilakukan bagi membuat perbandingan antara dua min dilakukan (Hanneman et al., 2012) yang melibatkan jantina guru matematik sekolah rendah. Manakala, analisis ANOVA satu hala pula dilaksanakan bagi membuat perbandingan skor min berdasarkan tempoh perkhidmatan kerana analisis ini membenarkan perbandingan pemboleh ubah yang mempunyai tiga atau lebih min dalam kalangan 
kumpulan dilakukan (Hanneman et al., 2012). Akhir sekali, bagi mencapai objektif ketiga, satu ujian regresi linear berganda telah dilaksanakan. Hal ini demikian kerana, ujian regresi berganda adalah kaedah analisis yang sesuai untuk digunakan apabila persoalan kajian melibatkan pemboleh ubah bersandar metrik yang tunggal yang dianggap mempunyai perkaitan dengan dua atau lebih pemboleh ubah bebas metrik (Hair et al., 2014).

\section{Hasil Kajian}

\section{Tahap Pengetahuan Guru Matematik Sekolah Rendah}

Analisis deskriptif yang melibatkan pengiraan skor min dan sisihan piawai dilaksanakan bagi meneliti tahap PT, PTIK, PTP dan PTPIK. Hasil analisis adalah seperti Jadual 4.

Jadual 4 : Tahap pengetahuan guru melibatkan elemen teknologi dalam Pengetahuan Teknologi Pedagogi dan Isi Kandungan (PTPIK)

\begin{tabular}{llll}
\hline Jenis Pengetahuan & $\begin{array}{l}\text { Skor } \\
\text { Min }\end{array}$ & Sisihan Piawai & Interpretasi \\
\hline Pengetahuan Teknologi (PT) & 3.456 & 0.827 & Tinggi \\
Pengetahuan Teknologi Isi Kandungan (PTIK) & 3.377 & 0.763 & Tinggi \\
$\begin{array}{l}\text { Pengetahuan Teknologi Pedagogi (PTP) } \\
\text { Pengetahuan Teknologi Pedagogi Isi Kandungan }\end{array}$ & 3.464 & 0.761 & Tinggi \\
(PTPIK) & 3.536 & 0.762 & Tinggi \\
\hline Skor Min Keseluruhan & 3.458 & 0.726 & Tinggi \\
\hline
\end{tabular}

Interpretasi berdasarkan perkiraan rumus oleh Tschannen-Moran dan Gareis (2004) mempamerkan bahawa tahap bagi keseluruhan dimensi pengetahuan-pengetahuan guru matematik yang diuji adalah tinggi $(\mathrm{M}=3.458, \mathrm{~S} . \mathrm{P}=0.726)$. Didapati dimensi Pengetahuan Teknologi $(\mathrm{PT})$ memperoleh min skor, $\mathrm{M}=3.456$ ( $\mathrm{S} . \mathrm{P}=0.827$ ), Pengetahuan Teknologi Isi Kandungan (PTIK) memperoleh skor min, $\mathrm{M}=$ 3.377 (S.P $=0.763)$, Pengetahuan Teknologi Pedagogi $(\mathrm{PTP})(\mathrm{M}=3.464$, S.P $=0.761)$ dan Pengetahuan Teknologi Pedagogi Isi Kandungan (PTPIK) memperoleh skor min, $\mathrm{M}=3.536$ (S.P = $0.762)$.

\section{Hipotesis nol : Tidak terdapat perbezaan kesediaan guru matematik sekolah rendah dalam pengintegrasian teknologi berdasarkan jantina.}

Ujian-t tidak bersandar dilaksanakan bagi membandingkan kesediaan guru matematik sekolah rendah dalam pengintegrasian teknologi antara guru matematik lelaki $(\mathrm{N}=17)$ dan guru matematik perempuan $(\mathrm{N}=45)$. Penganalisisan ini dilakukan dengan pemeriksaan pematuhan andaian-andaian ujian-t tidak bersandar. Ujian taburan normal Kolmogorov-Smirnov adalah tidak signifikan dengan nilai $\mathrm{p}>0.05$. Ini menunjukkan bahawa andaian taburan normal dipenuhi. Analisis varian turut menunjukkan ujian Levene adalah tidak signifikan pada nilai $p=0.398(p>0.05)$. Ini menunjukkan andaian kehomogenan varian dipenuhi. Jadual 4 menunjukkan hasil analisis deskriptif bagi kesediaan guru matematik sekolah rendah dalam pengintegrasian teknologi berdasarkan jantina.

Jadual 4 : Analisis deskriptif kesediaan guru matematik sekolah rendah dalam pengintegrasian teknologi berdasarkan jantina

\begin{tabular}{llll}
\hline \multirow{2}{*}{ Jantina } & \multicolumn{3}{c}{ Kesediaan Guru Matematik dalam Pengintegrasian Teknologi } \\
\cline { 2 - 4 } & Jumlah Responden, N & Skor Min & Sisihan Piawai \\
\hline Lelaki & 17 & 3.911 & 0.486 \\
Perempuan & 45 & 3.682 & 0.572 \\
\hline
\end{tabular}


DOI: https://doi.org/10.47405/mjssh.v6i8.949

Berdasarkan Jadual 5, hasil ujian-t tidak bersandar menunjukkan hasil tidak signifikan pada $\mathrm{t}(60)=$ 1.457; $p=0.150(p>0.05)$ dengan kesan ukuran Cohen's $d=0.424$. Ini bermakna bahawa hipotesis nol adalah gagal ditolak iaitu tiada perbezaan kesediaan dalam pengintegrasian teknologi antara guru matematik lelaki dan guru matematik perempuan.

Jadual 5 : Perbezaan kesediaan guru matematik sekolah rendah dalam pengintegrasian teknologi berdasarkan jantina

\begin{tabular}{lllllll}
\hline \multirow{2}{*}{$\begin{array}{l}\text { Pemboleh } \\
\text { ubah }\end{array}$} & \multicolumn{2}{l}{ Ujian Levene } & \multicolumn{2}{l}{ Ujian-t Bagi Persamaan Min } & \multirow{2}{*}{ Cohen's } \\
\cline { 2 - 6 } & Nilai F & Nilai Signifikan & Nilai-t & $\begin{array}{l}\text { Darjah } \\
\text { Kebebasan }\end{array}$ & $\begin{array}{l}\text { Nilai } \\
\text { Signifikan }\end{array}$ & $\mathrm{d}$ \\
\hline Kesediaan & 0.725 & 0.398 & 1.457 & 60 & 0.150 & 0.424 \\
\hline
\end{tabular}

\section{Hipotesis nol : Tidak terdapat perbezaan kesediaan guru matematik sekolah rendah dalam pengintegrasian teknologi berdasarkan tempoh perkhidmatan}

Analisis deskriptif perbezaan skor min kesediaan guru matematik sekolah rendah dalam pengintegrasian teknologi berdasarkan tempoh perkhidmatan adalah seperti dalam Jadual 8. Hasil menunjukkan guru matematik sekolah rendah yang mempunyai pengalaman kurang daripada 7 tahun yang mencatatkan nilai $\mathrm{M}=4.304$, S.P $=0.676$ adalah lebih tinggi berbanding guru matematik yang mempunyai pengalaman 7 tahun hingga 10 tahun $(\mathrm{M}=3.922$, S.P $=0.337), 11$ tahun hingga 18 tahun $(\mathrm{M}=3.862$, $\mathrm{S} . \mathrm{P}=0.481)$ dan 18 tahun ke atas $(\mathrm{M}=3.633$, $\mathrm{S} . \mathrm{P}=0.589)$.

Jadual 8 : Analisis deskriptif kesediaan guru matematik sekolah rendah dalam pengintegrasian teknologi berdasarkan tempoh perkhidmatan

\begin{tabular}{llll}
\hline $\begin{array}{l}\text { Kesediaan Guru Matematik dalam } \\
\text { Pengintegrasian Teknologi }\end{array}$ & N & Skor Min & Sisihan piawai \\
\hline Kurang dari 7 tahun & 2 & 4.304 & 0.676 \\
7 tahun hingga 10 tahun & 5 & 3.922 & 0.337 \\
11 tahun hingga 18 tahun & 18 & 3.862 & 0.481 \\
18 tahun ke atas & 37 & 3.633 & 0.589 \\
\hline
\end{tabular}

Keputusan analisis varian satu hala (ANOVA) antara kumpulan ditunjukkan pada Jadual 9 yang membuat perbandingan skor min kesediaan guru matematik sekolah rendah dalam pengintegrasian teknologi berdasarkan tempoh perkhidmatan. Ujian taburan normal Kolmogorov-Smirnov adalah tidak signifikan dengan nilai $\mathrm{p}>0.05$. Ini menunjukkan bahawa andaian taburan normal dipenuhi. Tambahan, Ujian Levene turut menunjukkan hasil p>0.05 dan keputusan ini memenuhi andaian kehomogenan varians. Keputusan ANOVA satu hala menunjukkan hasil tidak signifikan di mana $\mathrm{F}(3$, $58)=1.663, p=0.185(\mathrm{p}>0.05)$ dan ETA kuasa dua adalah 0.079. Keputusan ini menunjukkan hipotesis nol adalah gagal ditolak. Ini bermakna tiada perbezaan yang signifikan skor min kesediaan guru matematik sekolah rendah dalam pengintegrasian teknologi berdasarkan tempoh perkhidmatan. Secara statistiknya, hasil analisis ANOVA satu hala ini menunjukkan hasil adalah tidak signifikan dan perbezaan skor min sebenar antara kumpulan adalah kecil.

Jadual 9 : Analisis ANOVA satu hala kesediaan guru matematik sekolah rendah dalam pengintegrasian teknologi berdasarkan tempoh perkhidmatan

\begin{tabular}{llllll}
\hline $\begin{array}{l}\text { Kesediaan Guru } \\
\text { Matematik }\end{array}$ & $\begin{array}{l}\text { Jumlah Kuasa } \\
\text { Dua }\end{array}$ & $\begin{array}{l}\text { Darjah } \\
\text { Kebebasan }\end{array}$ & $\begin{array}{l}\text { Min Kuasa } \\
\text { Dua }\end{array}$ & Nilai F & $\begin{array}{l}\text { Nilai } \\
\text { Signifikan }\end{array}$ \\
\hline Antara Kumpulan & 1.491 & 3 & 0.497 & 1.663 & 0.185 \\
Dalam Kumpulan & 17.332 & 58 & 0.299 & & \\
Jumlah & 18.822 & 61 & & & \\
\hline
\end{tabular}


Hipotesis nol : Tidak terdapat perbezaan efikasi guru matematik sekolah rendah dalam pengintegrasian teknologi berdasarkan jantina.

Ujian-t tidak bersandar dilaksanakan bagi membandingkan efikasi guru matematik dalam pengintegrasian teknologi antara guru matematik lelaki $(\mathrm{N}=17)$ dan guru matematik perempuan $(\mathrm{N}=$ 45). Penganalisisan ini dilakukan dengan pemeriksaan pematuhan andaian-andaian ujian-t tidak bersandar. Ujian taburan normal Kolmogorov-Smirnov adalah tidak signifikan dengan nilai $\mathrm{p}>0.05$. Ini menunjukkan bahawa andaian taburan normal dipenuhi. Analisis varian turut menunjukkan ujian Levene adalah tidak signifikan pada nilai $p=0.728$ (p>0.05). Ini menunjukkan andaian kehomogenan varian dipenuhi. Jadual 6 menunjukkan hasil analisis deskriptif bagi kesediaan guru matematik dalam pengintegrasian teknologi berdasarkan jantina.

Jadual 6 : Analisis deskriptif efikasi guru dalam pengintegrasian teknologi berdasarkan jantina

\begin{tabular}{llll}
\hline \multirow{2}{*}{ Jantina } & \multicolumn{3}{l}{ Kesediaan Guru Matematik dalam Pengintegrasian Teknologi } \\
\cline { 2 - 4 } & Jumlah Responden, N & Skor Min & Sisihan Piawai \\
\hline Lelaki & 17 & 3.756 & 0.640 \\
Perempuan & 45 & 3.482 & 0.616 \\
\hline
\end{tabular}

Berdasarkan Jadual 5, hasil ujian-t tidak bersandar menunjukkan hasil tidak signifikan pada $\mathrm{t}(60)=$ $1.551 ; \mathrm{p}=0.126(\mathrm{p}>0.05)$ dengan kesan ukuran Cohen's $\mathrm{d}=0.451$. Ini bermakna bahawa hipotesis nol adalah gagal ditolak iaitu tiada perbezaan efikasi dalam pengintegrasian teknologi antara guru matematik lelaki dan guru matematik perempuan.

Jadual 7 : Perbezaan kesediaan dan efikasi guru matematik sekolah rendah dalam pengintegrasian teknologi berdasarkan jantina

\begin{tabular}{|c|c|c|c|c|c|c|}
\hline \multirow[b]{2}{*}{$\begin{array}{l}\text { Pemboleh } \\
\text { ubah }\end{array}$} & \multicolumn{2}{|c|}{ Ujian Levene } & \multicolumn{3}{|c|}{ Ujian-t Bagi Persamaan Min } & \multirow{2}{*}{$\begin{array}{l}\text { Cohen's } \\
\text { d }\end{array}$} \\
\hline & Nilai $\mathbf{F}$ & Nilai Signifikan & Nilai-t & $\begin{array}{l}\text { Darjah } \\
\text { Kebebasan }\end{array}$ & $\begin{array}{l}\text { Nilai } \\
\text { Signifikan }\end{array}$ & \\
\hline Efikasi & 0.122 & 0.728 & 1.551 & 60 & 0.126 & 0.451 \\
\hline
\end{tabular}

\section{Hipotesis nol : Tidak terdapat perbezaan efikasi guru matematik sekolah rendah dalam pengintegrasian teknologi berdasarkan tempoh perkhidmatan.}

Analisis deskriptif perbezaan skor min efikasi guru matematik sekolah rendah dalam pengintegrasian teknologi berdasarkan tempoh perkhidmatan adalah seperti dalam Jadual 10. Hasil menunjukkan guru matematik yang mempunyai pengalaman kurang daripada 7 tahun yang mencatatkan nilai $\mathrm{M}=4.095$, $\mathrm{S} . \mathrm{P}=0.673$ adalah lebih tinggi berbanding guru matematik yang mempunyai pengalaman 7 tahun hingga 10 tahun $(M=3.924$, $S . P=0.619), 11$ tahun hingga 18 tahun $(M=3.743, S . P=0.630)$ dan 18 tahun ke atas $(\mathrm{M}=3.387, \mathrm{~S} . \mathrm{P}=0.589)$.

Jadual 10 : Analisis deskriptif efikasi guru matematik dalam pengintegrasian teknologi berdasarkan tempoh perkhidmatan

\begin{tabular}{llll}
\hline $\begin{array}{l}\text { Efikasi Guru Matematik dalam } \\
\text { Pengintegrasian Teknologi }\end{array}$ & N & Skor Min & Sisihan piawai \\
\hline Kurang dari 7 tahun & 2 & 4.095 & 0.673 \\
7 tahun hingga 10 tahun & 5 & 3.924 & 0.619 \\
11 tahun hingga 18 tahun & 18 & 3.743 & 0.630 \\
18 tahun ke atas & 37 & 3.387 & 0.589 \\
\hline
\end{tabular}

Keputusan analisis varian satu hala (ANOVA) antara kumpulan ditunjukkan pada Jadual 11 yang membuat perbandingan skor min efikasi guru matematik sekolah rendah dalam pengintegrasian teknologi berdasarkan tempoh perkhidmatan. Ujian taburan normal Kolmogorov-Smirnov adalah tidak 
DOI: https://doi.org/10.47405/mjssh.v6i8.949

signifikan dengan nilai $\mathrm{p}>0.05$. Ini menunjukkan bahawa andaian taburan normal dipenuhi. Tambahan, Ujian Levene turut menunjukkan hasil p>0.05 dan keputusan ini memenuhi andaian kehomogenan varians. Keputusan ANOVA satu hala menunjukkan hasil tidak signifikan di mana $\mathrm{F}(3$, $58)=2.677, \mathrm{p}=0.055(\mathrm{p}>0.05)$ dan ETA kuasa dua adalah 0.122. Keputusan ini menunjukkan hipotesis nol adalah gagal ditolak. Ini bermakna tiada perbezaan yang signifikan skor min efikasi guru matematik dalam pengintegrasian teknologi berdasarkan tempoh perkhidmatan. Secara statistiknya, hasil analisis ANOVA satu hala ini menunjukkan hasil adalah tidak signifikan dan perbezaan skor min sebenar antara kumpulan adalah kecil.

Jadual 11 : Analisis ANOVA satu hala efikasi guru matematik sekolah rendah dalam pengintegrasian teknologi berdasarkan tempoh perkhidmatan

\begin{tabular}{llllll}
\hline $\begin{array}{l}\text { Efikasi Guru Matematik } \\
\text { dalam Pengintegrasian } \\
\text { Teknologi }\end{array}$ & $\begin{array}{l}\text { Jumlah } \\
\text { Kuasa Dua }\end{array}$ & $\begin{array}{l}\text { Darjah } \\
\text { Kebebasan }\end{array}$ & $\begin{array}{l}\text { Min } \\
\text { Kuasa } \\
\text { Dua }\end{array}$ & Nilai F & $\begin{array}{l}\text { Nilai } \\
\text { Signifikan }\end{array}$ \\
\hline $\begin{array}{l}\text { Antara Kumpulan } \\
\text { Dalam Kumpulan }\end{array}$ & 2.942 & 3 & 0.981 & 2.677 & 0.055 \\
Jumlah & 21.247 & 58 & 0.366 & & \\
\hline
\end{tabular}

Hipotesis nol : Tidak terdapat pengaruh antara Pengetahuan Teknologi (PT), Pengetahuan Teknologi Isi Kandungan (PTIK), Pengetahuan Teknologi Pedagogi (PTP) dan Pengetahuan Teknologi Pedagogi Isi Kandungan (PTPIK) dan efikasi guru matematik sekolah rendah ke atas kesediaan guru matematik sekolah rendah dalam pengintegrasian teknologi.

Analisis regresi linear berganda telah dilakukan bagi mengenal pasti hubungan antara PT, PTIK, PTP, PTIK dan efikasi guru matematik sekolah rendah ke atas kesediaan guru matematik sekolah rendah dalam mengintegrasikan teknologi. Beberapa andaian ujian regresi linear berganda telah dilakukan. Pertama, stem-and-leaf plots dan boxplots menunjukkan setiap pemboleh ubah dalam ujian regresi ini adalah bertaburan normal dan bebas daripada univariate outliers. Kedua, pemeriksaan ke atas normal $p-p$ plot of standardised residuals dan scatterplot of standardised residuals lawan standardised predicted values menunjukkan andaian taburan normal, linearity dan homoscedasticity of residuals adalah dipenuhi. Ketiga, nilai Mahalanobis turut tidak melebihi nilai kritikal $\chi^{2}(5)=20.157(\alpha=$ 0.001). Keempat, nilai Variance Inflation Factor (VIF) yang tidak melebihi 10 bagi peramal-peramal menunjukkan multicollinearity tidak menganggul dalam penafsiran keputusan analisis.

Hasil analisis menunjukkan bahawa sebanyak $66.1 \%$ variasi kesediaan guru matematik sekolah rendah dalam pengintegrasian teknologi dapat dijelaskan oleh PT, PTIK, PTP, PTIK dan efikasi guru matematik sekolah rendah, $\mathrm{R}^{2}=0.661$, adjusted $\mathrm{R}^{2}=0.631, \mathrm{~F}(5,56)=21.874, \mathrm{p}<0.001$. Keputusan memaparkan hanya peramal efikasi guru matematik sekolah rendah sahaja yang mempunyai hubungan linear yang signifikan pada $\mathrm{p}=0.003(\mathrm{p}<0.05)$. Pekali tidak standard $(B)$, pekali standard $(\beta)$ dan korelasi separa kuasa dua $\left(\mathrm{sr}^{2}\right)$ bagi setiap peramal adalah seperti dalam Jadual 12.

Jadual 12 : Hubungan antara elemen pengetahuan yang diuji dan efikasi guru matematik sekolah rendah ke atas kesediaan guru matematik sekolah rendah dalam pengintegrasian teknologi

\begin{tabular}{llllll}
\hline Model & $\mathbf{B}[\mathbf{9 5 \%}$ selang keyakinan] & $\boldsymbol{\beta}$ & $\mathbf{s r}^{\mathbf{2}}$ & $\mathbf{t}$ & $\begin{array}{l}\text { Nilai } \\
\text { Signifikan }\end{array}$ \\
\hline (Pemalar) & $1.191[0.690,1.691]$ & & & 4.765 & $\mathrm{p}<0.001$ \\
Efikasi & $0.645[0.233,1.056]$ & 0.731 & 0.244 & 3.137 & 0.003 \\
PT & $-0.019[-0.261,0.224]$ & -0.026 & -0.012 & -0.153 & 0.879 \\
PTIK & $-0.035[-0.413,0.343]$ & -0.044 & -0.014 & -0.185 & 0.854 \\
PTP & $0.000[-0.361,0.361]$ & 0.001 & 0.000 & 0.002 & 0.998 \\
PTPIK & $0.124[-0.107,0.356]$ & 0.166 & 0.084 & 1.078 & 0.286 \\
\hline $\mathrm{R}^{2}=0.661$ & & & & & \\
\hline
\end{tabular}


Adjusted $\mathrm{R}^{2}=0.631$

$\mathrm{F}(5,56)=21.874 ; \mathrm{p}<0.001$

Malanobis $($ maksimum $)=16.766$

\section{Perbincangan Kajian}

Berdasarkan analisis deskriptif, tahap Pengetahuan Teknologi (PT), Pengetahuan Teknologi Isi Kandungan (PTPIK), Pengetahuan Teknologi Pedagogi (PTP) dan Pengetahuan Teknologi Pedagogi Isi Kandungan (PTPIK) adalah berada di tahap yang tinggi. Ini mempamerkan bahawa guru matematik mempunyai pengetahuan yang baik akan pengintegrasian antara tiga ilmu utama iaitu pengetahuan isi kandungan, pengetahuan pedagogi dan pengetahuan teknologi. Namun, kajian ini tidak selari dengan kajian Valtonen et al. (2020) yang memberikan hasil pengetahuan guru masih berada di tahap yang rendah walaupun mempunyai sikap yang positif terhadap pengintegrasian teknologi. Seterusnya, kesediaan dan efikasi guru matematik dalam pengintegrasian teknologi berdasarkan faktor jantina tidak menunjukkan hasil yang signifikan. Ini memberi makna bahawa faktor jantina tidak memberikan kesan ke atas kesediaan dan efikasi guru matematik dalam pengintegrasian teknologi.

Hal ini berkemungkinan kerana, guru matematik biasa menggunakan teknologi dalam pengajaran mereka seperti kajian Mallillin et al. (2020) yang melaporkan hasil kajiannya yang tidak menunjukkan perbezaan yang signifikan terhadap kesediaan guru dalam menghadapi transisi pengajaran fizikal kepada atas talian kerana kebiasaan mereka menggunakan teknologi dalam pengajaran. Tambahan, hasil dapatan bagi efikasi guru matematik berdasarkan jantina adalah selari dengan kajian Abu Bakar et al. (2020) yang menemukan hasil yang sama. Adapun begitu, kajian Farah (2011) menunjukkan hasil yang berlainan iaitu guru lelaki lebih ramai yang berefikasi tinggi dalam pengintegrasian teknologi berbanding guru perempuan. Menariknya, (Farah, 2011) turut mengemukakan beberapa faktor yang mampu mempengaruhi efikasi guru dalam pengintegrasian teknologi. Antaranya adalah persepsi guru terhadap sokongan sekolah, pengetahuan pengajaran berasaskan teknologi guru, tempoh waktu yang dimanfaatkan guru dalam melaksanakan pengajaran berasaskan teknologi, kepercayaan terhadap peluang yang terbentang bagi menambahbaikkan ilmu pengintegrasian teknologi, personaliti dan sikap guru, akses dan sumber teknologi serta ketakutan guru dalam mengintegrasikan teknologi (Farah, 2011).

Selain itu, dapatan kajian turut menunjukkan tidak terdapat perbezaan kesediaan dan efikasi guru matematik dalam pengintegrasian teknologi berdasarkan tempoh perkhidmatan. Ini memberi makna bahawa tempoh perkhidmatan tidak memberikan kesan ke atas kesediaan dan efikasi guru matematik dalam pengintegrasian teknologi. Walau bagaimanapun, hasil kajian ini adalah bertentangan dengan hasil kajian Bahador et al. (2018) yang menunjukkan skor min yang berbeza berkaitan tempoh pengalaman yang bertahun-tahun. Hal ini berkemungkinan kerana, guru matematik yang mempunyai tahap pengetahuan isi kandungan yang kukuh akan lebih cenderung dan berkebolehan dalam mengadunkan teknologi dalam pengajaran. Selain daripada itu, hasil analisis regresi linear berganda turut mempamerkan bahawa kesediaan guru matematik dalam mengintegrasikan teknologi dipengaruhi oleh efikasi guru matematik. ELDaou (2016), Farah (2011) dan Wang et al. (2004) turut mendapati bahawa efikasi adalah antara faktor yang memainkan peranan ke atas keputusan guru dalam pengintegrasian teknologi. Hal ini demikian kerana, kepercayaan dan sikap guru terhadap penggunaan teknologi adalah pertimbangan genting dalam menjayakan pengintegrasian teknologi (Fontanilla, 2015; Jung et al., 2019)

\section{Kesimpulan}

Sedia maklum, konstruk PTPIK oleh Mishra dan Koehler (2006) mampu melengkapi proses pengajaran guru matematik dengan mengambil kira kehendak pengajaran semasa, kehendak pelajar dan karakteristik pelajar. Walaupun dapatan kajian ini menunjukkan tahap pengetahuan guru matematik dalam setiap elemen PTPIK yang mempunyai pengetahuan teknologi adalah tinggi, namun, proses pembinaan domain pengetahuan guru perlu dipantau secara berterusan (Tay, 2017). Ini bagi 
memastikan guru matematik sentiasa mengambil cakna akan tahap PTPIK mereka, berfikir secara makro dan menyeluruh bagi menyusun strategi yang kreatif dan inovatif untuk penambahbaikan proses pengajaran dan pembelajaran.

Dapatan kajian turut menunjukkan tiada perbezaan kesediaan dan efikasi guru matematik dalam pengintegrasian teknologi berdasarkan jantina dan tempoh perkhidmatan. Adapun begitu, bagi memastikan kesediaan dan efikasi guru matematik sentiasa berada pada tahap yang memuaskan, Latihan Dalam Perkhidmatan (LDP) adalah penting untuk dilaksanakan. Latihan Dalam Perkhidmatan (LDP) menyumbang kepada Perkembangan Profesionalisme Berterusan (PPB) di mana guru matematik dapat melengkapkan atau dilengkapkan dengan pengetahuan, kemahiran, nilai dan amalan profesional keguruan. Kelengkapan pengetahuan profesionalisme bagi tujuan pembangunan kompetensi tidak harus diketepikan terutamanya kompetensi teknologi. Ini diibaratkan seperti satu penggera kepada pihak berkenaan dalam memberikan latihan-latihan komprehensif yang bersesuaian dan terkini bagi membantu keberkesanan proses PdP atas talian. Malahan, dengan adanya PPB yang berterusan, tindakan ini boleh menyebabkan guru matematik akan lebih bersedia, berkeyakinan dan berkeupayaan dalam menggunakan teknologi dalam pengajaran atas talian sewaktu COVID-19.

Kesimpulannya, tidak dinafikan, kesediaan guru matematik adalah didasarkan pada kepercayaan terhadap manfaat pendidikan berasaskan teknologi dan keyakinan terhadap keupayaan diri dalam menggunakan teknologi, mampu untuk melonjakkan lagi peratusan pengintegrasian teknologi dalam PdP dalam kalangan guru yang bukan hanya bergantung kepada modul dan bahan bercetak sematamata. Menyedari hakikat di atas, banyak usaha yang perlu dilakukan bagi memastikan keberhasilan pengajaran matematik sewaktu pandemik COVID-19. Hal ini demikian kerana, kehadiran faktor halangan yang lain mampu untuk mempengaruhi kesediaan, motivasi dan tabiat seseorang guru matematik. Oleh yang demikian, bagi mendapatkan pandangan yang lebih komprehensif, faktor lain seperti lokaliti sekolah dapat dilakukan pada masa akan datang dengan saiz sampel yang lebih besar.

\section{Rujukan}

Abdul Hamid, H., \& Khalidi, J. R. (2020). COVID-19 and unequal learning (Issue April, pp. 1-8). Khazanah Research Institute. http://www.krinstitute.org/Views-@-Covid19_and_Unequal_Learning.aspx

Akturk, A. O., \& Saka Ozturk, H. (2019). Teachers' TPACK levels and students' self-efficacy as predictors of students' academic achievement. International Journal of Research in Education and Science, 5(1), 283-294.

Ali, W. (2020). Online and remote learning in higher education institutes: A necessity in light of COVID-19 pandemic. Higher Education Studies, 10(3), 16-25. https://doi.org/10.5539/hes.v10n3p16

Alshehri, K. A. (2012). The influence of mathematics teachers' knowledge in Technology, Pedagogy and Content (TPACK) on their teaching effectiveness in Saudi Public Schools [Doctor of Philosophy, University of Kansas.]. Ihttps://www.learntechlib.org/p/41968/

Amick, M. (2019). The impact of 1:1 technology initiatives on teacher planning [Doctor of Philosophy, Duquesne https://dsc.duq.edu/cgi/viewcontent.cgi?article=2771\&context=etd

Antonelli, S. (2019). Teacher perceptions of technological knowledge and pedagogy in Mathematics instruction in a Northeast State [Doctor of Philosophy, Johnson \& Wales University.]. https://search.proquest.com/openview/9a48bd8eb750a56f1e9abe1e06578ff3/1?pqorigsite $=$ gscholar $\&$ cbl $=18750 \&$ diss $=y$

Awofala, A. O. A., Lawal, R. F., Isiakpere, B. J., Arigbabu, A. A., \& Fatade, A. O. (2020). COVID-19 pandemic in Nigeria and attitudes towards Mathematics homeschooling among pre-tertiary students. Nigerian Online Journal of Educational Sciences and Technology (NOJEST), 1(2), 5770 .

Bahasoan, A., Ayuandiani, W., Mukhram, M., \& Rahmat, A. (2020). Effectiveness of Online Learning In Pandemic Covid-19. International Journal Of Science, Technology \& Management, 1(2), 100106. https://ijstm.inarah.co.id/index.php/ijstm/article/view/30 
Bhattacherjee, A. (2012). Social science research: Principles, methods, and practices ( $2^{\text {nd }}$ ed.). Creative Commons Attribution-NonCommercial-ShareAlike 3.0 Unported License. http://scholarcommons.usf.edu/cgi/viewcontent.cgi?article=1002\&context=oa_textbooks

Brown, S. M. (2015). Interactive whiteboards and TPACK for technology-enhanced learning: Secondary mathematics teachers' barriers, beliefs, and support needs in one rural school district. [Doctor of Philosophy, Mississippi State University].

Chaaban, Y., \& Moloney, R. (2016). Educating pre-service teachers in technology use: a study of provision at Lebanese Universities. International Journal of Education, 8(2), 14-31. https://doi.org/10.5296/ije.v8i2.9188

Creswell, J. W. (2014). Research design: Qualitative, quantitative and mixed methods approaches $\left(4^{\text {th }}\right.$ ed.). SAGE Publications Inc.

Dinc, E. (2019). Prospective teachers' perceptions of barriers to technology integration in education. Contemporary Educational Technology, 10(4), 381-398. https://doi.org/10.30935/cet.634187

Dong, Y., Xu, C., Chai, C. S., \& Zhai, X. (2020). Exploring the Structural Relationship Among Teachers' Technostress, Technological Pedagogical Content Knowledge (TPACK), Computer Self-efficacy and School Support. Asia-Pacific Education Researcher, 29(2), 147-157. https://doi.org/10.1007/s40299-019-00461-5

Durak, H. Y. (2019). Modeling of relations between K-12 teachers' TPACK levels and their technology integration self-efficacy, technology literacy levels, attitudes toward technology and usage objectives of social networks. Interactive Learning Environments, $0(0), 1-27$. https://doi.org/10.1080/10494820.2019.1619591

El-daou, B. M. N. (2016). The effect of using computer skills on teachers' perceived self- efficacy beliefs towards technology integration, attitudes and performance. World Journal on Educational Technology, 8(2), 106-118.

ELDaou, B. (2016). The relationship between teacher's self-efficacy, attitudes towards ICT usefulness and student's science performance in the Lebanese Inclusive Schools 2015. Acta Psychopathologica, 2(3), 1-10. https://doi.org/10.4172/2469-6676.100054

Ertmer, P. A. (1999). Addressing first- and second-order barriers to change: Strategies for technology integration. Educational Technology Research and Development, 4(47), 47-61. https://link.springer.com/content/pdf/10.1007\%2FBF02299597.pdf\%0Ahttps://link.springer.com/ content/pdf/10.1007\%2FBF02299597.pdf\%0Ahttp://download.springer.com/static/pdf/155/art\%2 53A10.1007\%252FBF02299597.pdf?auth66=1393957450_9f37f14fbe720aad62eb78240cc8

Etikan, I. (2016). Comparison of Convenience Sampling and Purposive Sampling. American Journal of Theoretical and Applied Statistics, 5(1), 1. https://doi.org/10.11648/j.ajtas.20160501.11

Fahrurozi, S. K., Budiyanto, C., \& Roemintoyo. (2019). Pre-service teachers perspective in developing TPACK: Literature review. AIP Conference Proceedings, 2194(December). https://doi.org/10.1063/1.5139756

Farah, A. C. (2011). Factors influencing teachers' technology self-efficacy: A case study [Doctor of Philosophy, Liberty University.]. https://core.ac.uk/download/pdf/58824405.pdf

Fontanilla, H. S. (2015). Comparison of beginning teachers' and experienced teachers' readiness to integrate technology as measured by TPACK scores [Doctor of Philosophy, Brandman University.]. https://digitalcommons.brandman.edu/edd_dissertations/78/

Graham, C. R., Borup, J., Pulham, E., \& Larsen, R. (2019). K-12 blended teaching readiness: Model and istrument development. Journal of Research on Technology in Education, 51(3), 239-258. https://doi.org/10.1080/15391523.2019.1586601

Hair, J. F., Black, W. C., Babin, B. J., \& Anderson, R. E. (2014). Multivariate data analysis (7 th $^{\text {ed.). }}$ Pearson Education Limited.

Hanneman, R. A., Kposowa, A. J., \& Riddle, M. D. (2012). Basic statictics for social research (1 ${ }^{\text {st }}$ ed.). John Wiley \& Sons Inc.

Hebebci, M. T., Bertiz, Y., \& Alan, S. (2020). Investigation of views of students and teachers on distance education practices during the Coronavirus (COVID-19) pandemic. International Journal of Technology in Education and Science, 4(4), 267-282. https://doi.org/10.46328/ijtes.v4i4.113

Hew, K. F., \& Brush, T. (2007). Integrating technology into K-12 teaching and learning: Current knowledge gaps and recommendations for future research. Education Tech Research Dev, 55(0), 223-252. https://doi.org/10.1007/s11423-006-9022-5 
Holden, H., \& Rada, R. (2011). Understanding the influence of perceived usability and technology self-efficacy on teachers' technology acceptance. Journal of Research on Technology in Education, 43(4), 343-367. https://doi.org/10.1080/15391523.2011.10782576

Humes, V. (2017). The impact of TPACK, SAMR, and teacher effectiveness on student academic growth in eighth grade Language Art and Mathematics [Doctor of Philosophy, Youngstown State University.]. https://etd.ohiolink.edu/apexprod/rws_olink/r/1501/10?p10_etd_subid=160680\&clear=10

İşler, C., \& Yıldırım, Ö. (2018). Perceptions of Turkish pre-service EFL teachers on their Technological Pedagogical Content Knowledge. Journal of Education and Future, 13, 145-160.

Jan, A. (2020). Online teaching practices during COVID-19: An observation case study. SSRN Electronic Journal. https://doi.org/10.2139/ssrn.3584409

Johns, C., \& Mills, M. (2020). Online Mathematics tutoring during the COVID-19 pandemic: Recommendations for best practices. Problems, Resources, and Issues in Mathematics Undergraduate(PRIMUS), O(0), 1-32. https://doi.org/10.1080/10511970.2020.1818336

Jung, Y. J., Cho, K., \& Shin, W. S. (2019). Revisiting critical factors on teachers' technology integration: The differences between elementary and secondary teachers. Asia Pacific Journal of Education, 39(4), 548-561. https://doi.org/10.1080/02188791.2019.1620683

Kamsurya, R. (2020). Learning evaluation of Mathematics during the pandemic period COVID-19 in Jakarta. International Journal of Pedagogical Development and Lifelong Learning, 1(2), ep2008. https://doi.org/10.30935/ijpdll/8439

Kapici, H. O., \& Akcay, H. (2020). Improving student teachers' TPACK self-efficacy through lesson planning practice in the virtual platform. Educational Studies, O(0), 1-23. https://doi.org/10.1080/03055698.2020.1835610

Kariki, S., Mohd Zaki, I., \& Fook, F. S. (2017). Keperluan instrumen ptpk-ipg untuk merealisasikan kompetensi mengintegrasikan teknologi maklumat dan komunikasi dalam pembelajaran dan pemudahcaraan. Jurnal Kinabalu, 3(0), 115-138.

Kementerian Pendidikan Malaysia. (2020). Pemakluman pelaksanaan pengajaran dan pembelajaran di rumah. https://www.moe.gov.my/pemberitahuan/kenyataan-media/km-kpm-pengoperasianinstitusi-pendidikan-kpm-seluruh-negara

Kementerian Pendidikan Malaysia. (2021). Pengoperasian institut pendidikan bawah Kementerian Pendidikan Malaysia seluruh Negara. https://www.moe.gov.my/pemberitahuan/kenyataanmedia/km-kpm-pengoperasian-institusi-pendidikan-kpm-seluruh-negara

Knapp, W. M. (2017). The impact of TPACK and teacher technology efficacy on social studies teachers' use of teachnology in the classroom [Doctor of Philosophy, University of Minnesota.]. http://search.ebscohost.com/login.aspx?direct=true \&db=ddu\&AN=230B8EBB287B01CB\&lang= tr\&site=ehost-live

König, J., Jäger-Biela, D. J., \& Glutsch, N. (2020). Adapting to online teaching during COVID-19 school closure: Teacher education and teacher competence effects among early career teachers in Germany. European Journal of Teacher Education, 43(4), 608-622. https://doi.org/10.1080/02619768.2020.1809650

Lapada, A. A., Miguel, F. F., Robledo, D. A. R., \& Alam, Z. F. (2020). Teachers' COVID-19 awareness, distance learning education experiences and perceptions towards institutional readiness and challenges. International Journal of Learning, Teaching and Educational Research, 19(6), 127-144. https://doi.org/10.26803/ijlter.19.6.8

Mailizar, Almanthari, A., Maulina, S., \& Bruce, S. (2020). Secondary school mathematics teachers' views on e-learning implementation barriers during the COVID-19 pandemic: The case of Indonesia. Eurasia Journal of Mathematics, Science and Technology Education, 16(7), 1-9. https://doi.org/10.29333/EJMSTE/8240

Mallillin, L. L. D., Mendoza, L. C., Mallillin, J. B., Felix, R. C., \& Lipayon, I. C. (2020). Implementation and readiness of online learning pedagogy: A transition to COVID 19 pandemic. European Journal of Open Education and E-Learning Studies, 5(2), 71-90. https://doi.org/10.46827/ejoe.v5i2.3321

Maneesriwongul, W., \& Dixon, J. K. (2004). Instrument translation process: A methods review. Journal of Advanced Nursing, 48(2), 175-186. https://doi.org/10.1111/j.1365-2648.2004.03185.x

Martin, F., Budhrani, K., \& Wang, C. (2019). Examining faculty perception of their readiness to teach online. Online Learning Journal, 23(3), 97-119. https://doi.org/10.24059/olj.v23i3.1555 
Mishra, P., \& Koehler, M. J. (2006). Technological Pedagogical Content Knowledge: A framework for teacher knowledge. Teachers College Record, 108(6), 1017-1054. https://doi.org/10.1111/j.1467-9620.2006.00684.x

Mohalik, R., \& Sahoo, S. (2020). E-Readiness and perception of student teachers' towards online learning in the midst of COVID-19 pandemic. SSRN Electronic Journal, August 4, 0. https://doi.org/10.2139/ssrn.3666914

Mulenga, E. M., \& Marbán, J. M. (2020). Prospective teachers' online learning mathematics activities in the age of COVID-19: A cluster analysis approach. Eurasia Journal of Mathematics, Science and Technology Education, 16(9), 1-9. https://doi.org/10.29333/EJMSTE/8345

Nurul Shahhida, A. B., Siti Mistima, M., \& Roslinda, R. (2020). Mathematics teacher's self-efficacy of technology integration and Technological Pedagogical Content Knowledge. Journal on Mathematics Education, 11(2), 256-276. https://doi.org/10.22342/jme.11.2.10818.259-276

Petko, D., Prasse, D., \& Cantieni, A. (2018). The interplay of school readiness and teacher readiness for educational technology integration: A structural equation model. Computers in the Schools, 35(1), 1-18. https://doi.org/10.1080/07380569.2018.1428007

Poyo, S. R. (2016). Transforming traditional practices of teacher preparation to meet changing needs of digital learners: A first step intervention by assessing and addressing needs of pre-service teachers in a dual learning environment. [Doctor of Philosophy, Duquesne University.].

Putra, Z. H., Witri, G., \& Sari, I. K. (2020). Prospective elementary teachers' perspectives on online mathematics learning during coronavirus outbreak. Journal of Physics: Conference Series, 1655(1), 1-6. https://doi.org/10.1088/1742-6596/1655/1/012057

Sahin Izmirli, O., \& Kirmaci, O. (2017). New barriers to technology integration. Egitim Arastirmalari Eurasian Journal of Educational Research, 2017(72), 147-166. https://doi.org/10.14689/ejer.2017.72.8

Salwana, M., \& Norasmah, O. (2020). Kesahan dan Kebolehpercayaan Instrumen Kecerdasan Menghadapi Cabaran Teknologi Menggunakan Model Rasch. Akademika, 90(Khas 3), 29-41.

Sarwa, Simaremare, A., Hasibuan, N. I., \& Priyadi, M. (2020). Teacher readiness in accommodating the TPACK framework to meet teacher competence the 21st Century. Journal of Physics: Conference Series, 1511(1), 1-7. https://doi.org/10.1088/1742-6596/1511/1/012041

Şen, Ş. (2020). Modelling the relations between Turkish chemistry teachers' sense of efficacy and technological pedagogical content knowledge in context. Interactive Learning Environments, O(0), 1-14. https://doi.org/10.1080/10494820.2020.1712430

Simsek, O., \& Yazar, T. (2019). Examining the self-efficacy of prospective teachers in technology integration according to their subject areas: The case of Turkey. Contemporary Educational Technology, 10(3), 289-308. https://doi.org/10.30935/cet.590105

Sokal, L., Trudel, L. E., \& Babb, J. (2020). Canadian teachers' attitudes toward change, efficacy, and burnout during the COVID-19 pandemic. International Journal of Educational Research Open, l(November), 100016. https://doi.org/10.1016/j.ijedro.2020.100016

Tay, M. G. (2017). Pengetahuan Teknologi Pedagogi Kandungan dalam kalangan pelajar institut pendidikan guru. Jurnal Penyelidikan IPGKBL, 14(0), 17-28.

Tiba, C., \& Condy, J. L. (2021). Identifying factors influencing pre-service teacher readiness to use technology during professional practice. International Journal of Information and $\begin{array}{llll}\text { Communication Technology } & \text { Education, } & \text { 17(2), }\end{array}$ https://doi.org/10.4018/IJICTE.20210401.oa2

Tschannen-Moran, M., \& Gareis, C. R. (2004). Principals' sense of efficacy: Assessing a promising construct. Journal of Educational Administration, 42(5), 573-585. https://doi.org/10.1108/09578230410554070

UNESCO. (2020). COVID-19 educational disruption and response. https://en.unesco.org/news/covid19-educational-disruption-and-response

Valtonen, T., Leppänen, U., Hyypiä, M., Sointu, E., Smits, A., \& Tondeur, J. (2020). Fresh perspectives on TPACK: pre-service teachers' own appraisal of their challenging and confident TPACK areas. Education and Information Technologies, 25(4), 2823-2842. https://doi.org/10.1007/s10639-019-10092-4

Vasantha Raju, N., \& Harinarayana, N. S. (2016). Online survey tools : A case study of Google Forms online. National Conference on "Scientific, Computational \& Information Research Trends in Engineering, GSSS-IETW, Mysore, January 2016, 1-12. 
DOI: https://doi.org/10.47405/mjssh.v6i8.949

Wang, L., Ertmer, P. A., \& Newby, T. J. (2004). Increasing preservice teachers' self-efficacy beliefs for technology integration. Journal of Research on Technology in Education, 36(3), 231-250. https://doi.org/10.1080/15391523.2004.10782414

Yang, L. (2018). Fuzzy cluster correlation mapping for online evaluation of teaching efficacy towards IoT study. Cognitive Systems Research, 52(July), 365-370. https://doi.org/10.1016/j.cogsys.2018.07.025

Zolkefli, B., Nordin, O., \& Mohd Kasri, S. (2018). Faktor-faktor yang mempengaruhi pengintegrasian teknologi pengajaran berdasarkan model TPACK dalam kalangan guru matematik. Proceedings of the ICECRS, 1(2), 66-73. https://doi.org/10.21070/picecrs.v1i2.1438 